\title{
Growth and Foliar Yield Responses of Waterleaf (Talinum triangulare Jacq) to Complementary Application of Organic and Inorganic Fertilizers in a Ultisol
}

\author{
N. U. Ndaeyo ${ }^{1 *}$, A. O. Ikeh ${ }^{1}$, K. K. Nkeme ${ }^{2}$, E. A. Akpan ${ }^{3}$ and E. I. Udoh ${ }^{3}$ \\ ${ }^{1}$ Department of Crop Science, University of Uyo, Akwa Ibom State, Nigeria. \\ ${ }^{2}$ Department of Agric. Economics and Resource Management, Akwa Ibom State University, \\ Obio Akpa Campus, Nigeria. \\ ${ }^{3}$ Department of Crop Science and Horticulture, Akwa Ibom State University, Obio Akpa \\ Campus, Akwa Ibom State, Nigeria.
}

\section{Authors' contributions}

This work was carried out in collaboration between all authors. Author NUN designed the study and performed the statistical analysis, author AOI wrote the protocol, while author KKN wrote the first draft of the manuscript. Author EAA analyzed of the study. Author EIU managed the literature searches. All authors read and approved the final manuscript.

Research Article

Received $17^{\text {th }}$ November 2012 Accepted $8^{\text {th }}$ February 2013 Published 11 ${ }^{\text {th }}$ March 2013

\section{ABSTRACT}

Aims: Growth and foliar yield responses of waterleaf (Talinum triangulare Jacq) to complementary application of organic and inorganic fertilizers were studied in a Ultisol.

Study Design: The experiment was laid out in a randomized complete block design with three replicates.

Place and Duration of Study: The University of Uyo Teaching and Research Farm, located at Use Offot - Uyo, Akwa Ibom State, Nigeria and was conducted between March, 06 and June, 06 in both 2009 and 2010 cropping seasons.

Methodology: Treatments were various combinations of organic and inorganic fertilizers applied to the soil, and these included NPK $(15: 15: 15)$ at $400 \mathrm{~kg} \mathrm{ha}^{-1}$, poultry manure (PM) at $5 \mathrm{t} \mathrm{ha}^{-1}, \mathrm{PM}$ at $2.5 \mathrm{tha}^{-1}+\mathrm{NPK}$ at $200 \mathrm{kgha}^{-1}, \mathrm{PM}$ at $3.75 \mathrm{tha}^{-1}+\mathrm{NPK}$ at $100 \mathrm{kgha}^{-1}, \mathrm{PM}$ at 1.25 tha $^{-1}+\mathrm{NPK}$ at $300 \mathrm{kgha}^{-1}$ and control (without amendment).

Results: There were significant differences $(P<0.05)$ among treatments in height, number 
of branches, number of leaves, stem girth, leaf area, and total foliage yield of waterleaf in both years. Generally, application of PM alone and complementary use of PM and NPK, irrespective of the ratio, enhanced waterleaf growth and total foliage yield better compared to application of NPK alone and the control treatment. Total foliage yield from $100 \mathrm{kgha}^{-1}$ NPK + 3.75 tha $^{-1}$ of PM treatment (56.03 tha ${ }^{-1} 30$ and 5436 tha $^{-1} 31$ in 2009 and 2010, respectively) superseded other treatments by $38-78 \%$ in 2009 and $35-78 \%$ in 2010 .

Conclusion: With the high cost, scarcity, and environmental problems associated with the use of mineral fertilizer in Nigeria; and based on the foliage yield obtained in this study, it is obvious that the use of organic manure in combination with mineral fertilizer (particularly with $100 \mathrm{kgha}^{-1} \mathrm{NPK}+3.75 \mathrm{tha}^{-1} \mathrm{PM}$ or $200 \mathrm{kgha}^{-1} \mathrm{NPK}+2.5$ tha $^{-1} \mathrm{PM}$ treatment) can sustain waterleaf production. It is also demonstrated that it would be more rewarding to apply 5tha ${ }^{-}$ ${ }^{1} \mathrm{PM}$ alone compared to sole application of $400 \mathrm{kgha}^{-1}$ mineral fertilizer for waterleaf production in a Ultisol.

Keywords: Waterleaf; organic inorganic fertilizers; growth; foliar yield; ultisol.

\section{INTRODUCTION}

Waterleaf (Talinum triangulare Jacq), a leafy vegetable crop that originated from tropical Africa [1], is an all -season vegetable that is extensively grown in many countries in Asia, South America and West Africa. In Nigeria, it is widely cultivated and consumed in the southern part, particularly in Cross River and Akwa Ibom States [2,3]. The demand for waterleaf is high in these states, and it is therefore a major source of income for farmers. Its high demand is attributed to its nutritional value and importance as a "softener" when cooking the common fibrous leafy vegetables [4] such as Afang (Gnetum africana), Atama (Heinsia crinata), and Editan (Lasienthera bulchozianum). It is also cooked with green amaranthus (Amaranthus curentus) and fluted pumpkin (Telfairia occidentalis). Waterleaf has a colloidal property and this favours its use for preparation of popular soups known as Ukwoho afang and edikang ikong in some parts of southern Nigeria. Ibeawuchi et. al. [5] stated that the leaves and young shoots are used to thicken sauce and is consumed in large quantities in the southern part of Nigeria. It is considered medicinal in southern Nigeria as it is used as herb for measles and stomach upsets [3]. Also, it performs well as fodder for raising giant snails [6].

The increasing demand for waterleaf due to urbanization has therefore pushed farmers into small and medium scale production of waterleaf in Akwa lbom State. Consequently, to obtain optimum yield, organic fertilizers are being developed by farmers from farm and city wastes for vegetable production. Also, organo-mineral fertilizers (OMF) in which organic wastes are fortified with inorganic N or NP fertilizers are being utilized by crop farmers. Organic and organo-mineral fertilizers have been reported to significantly increase yield of vegetables such as pepper (Capsicum annum), tomato (Lycopersicon esculentus), okra (Abelmoschus esculentus), egusi-melon (Cucumeropsis mannii) and amaranthus (Amaranthus cruentus) $[7,8,9,10,11,12,13,14]$.

Most farmers apply these assorted types of fertilizers (organic and inorganic) but sometimes the yields hardly compensate for the money spent to purchase these fertilizers. This is partly because most farmers are yet to determine the best local fertilizer source to use in the vegetable crop production. The use of animal and plant wastes in crop production is indeed a long standing practice in the world. The use of inorganic fertilizers among farmers to 
improve waterleaf yield is also common although some farmers and consumers still question the desirability of using inorganic fertilizer for leafy vegetable production. Most farmers broadcast large quantity of inorganic fertilizer in waterleaf plots at intervals of 2 to 30 weeks to stimulate growth. This is always aimed at achieving maximum growth and yields $[15,16]$. The inorganic fertilizer is considered a major source of plant nutrients [17] while organic manure has ability of improving soil structure in addition to supplying nutrients [16] and increasing microbial biomass [18]. However, the use of inorganic fertilizers alone may have negative implications for human health and the environment [19]. The utilization of organic manures by vegetable producers may have an additional advantage of ensuring environmental harmony compared to chemical fertilizers.

Udoh et. al. [3] recommended application of organic manures like cow dung, poultry droppings and nitrogenous fertilizers immediately after harvest. Farmers find it difficult to maintain a standard fertilizer regime in the cultivation of water leaf as they often supplement organic manure with mineral fertilizers. However, information on the interaction due to combined application of organic manure and mineral fertilizer for waterleaf is scanty. Combined application of organic manure and mineral fertilizers often goes with such additional advantages as buffering the soil against undesirable acidification and increasing the availability of micronutrients [20]. The blending of organic manures with mineral fertilizer may help to increase the productivity of crops on fragile soil by reducing the problem of nutrient losses via leaching or denitrification. Olsen et. al. [21] found that a substantial portion of nitrogen fertilizer needs of most cereals could be met by organic manure blended with mineral fertilizer. The use of both mineral and organic fertilizers has been found to be a sustainable technology for crop production, and the full integration of this technology into the cropping systems of Akwa Ibom State could further increase crop yields [22]. Improved vegetable crop growth and yield performances with complementary application of inorganic and organic fertilizers compared to sole application of either organic or inorganic fertilizer have been reported $[23,22,24,25,26]$.

The complementary use of organic manure and inorganic fertilizers have been proven to be a sound soil fertility management and crop production strategy in many countries of the world $[27,28]$. In Nigeria, Makinde et al. [29] in their study on combined application of organic manures and mineral fertilizers recommended the use of either kola pod husk and pacesetter organic fertilizer at 3 tha $^{-1}$ alone or combined with NPK fertilizer at reduced levels as being suitable for improving yield and nutritional quality of amaranthus. High and sustained crop growth and yield could therefore be obtained with combined and judicious use of balanced inorganic and organic fertilizers. This study was therefore conducted to evaluate the effects of amending the soil with different organic manures supplemented with a nitrogen fertilizer on growth and foliar yield of waterleaf in Uyo, southeastern Nigeria.

\section{MATERIALS AND METHODS}

\subsection{Experimental Site}

The experiment was conducted at the University of Uyo Teaching and Research Farm, located at Use-Offot- Uyo, Akwa Ibom State of Nigeria and was conducted between March, 06 and June, 06 in both 2009 and 2010 early cropping seasons. The site is located at Latitude $5^{\circ} 17^{\prime}$ and $5^{\circ} 27^{\prime} \mathrm{N}$, Longitude $7^{\circ} 27^{\prime}$ and $7^{\circ} 58^{\prime} \mathrm{E}$ and on altitude of $38.1 \mathrm{~m}$ above sea level. This rainforest zone receives about $2500 \mathrm{~mm}$ rainfall annually. The rainfall pattern is bimodal, with long (March - July) and short (September - November) rainy seasons 
separated by a short dry spell of uncertain length usually during the month of August. The mean relative humidity is $78 \%$ and the atmospheric temperature is $30^{\circ} \mathrm{C}$. The mean sunshine hour is 12 [30]. Soil analysis revealed the following physico-chemical characteristics: $\mathrm{pH}$ in water of $5.6,1.37 \%$ organic matter, $0.10 \%$ total nitrogen, $31.77 \mathrm{mg} / \mathrm{kg}$ available $P$ while exchangeable bases values were $199.02,2.88$ and $1.20 \mathrm{cmolkg}^{-}{ }^{1}$ for K, $\mathrm{Ca}$ and $\mathrm{Mg}$, respectively. The soil particle distribution was: sand $86.9 \%$, silt $2.8 \%$ and clay $10.3 \%$.

\subsection{Experimental Design, Treatment and Cultural Details}

The experiment was laid out in a randomized complete block design with three replicates. Treatments were six fertilizer rates: NPK $(15: 15: 15)$ at $400 \mathrm{~kg} \mathrm{ha}^{-1}$, poultry manure (PM) at 5 $\mathrm{t} \mathrm{ha}{ }^{-1}, \mathrm{PM}$ at $2.5 \mathrm{tha}^{-1}+\mathrm{NPK}$ at $200 \mathrm{kgha}^{-1}, \mathrm{PM}$ at $3.75 \mathrm{tha}^{-1}+\mathrm{NPK}$ at $100 \mathrm{kgha}^{-1}, \mathrm{PM}$ at 1.25 tha $^{-1}+\mathrm{NPK}$ at $300 \mathrm{kgha}^{-1}$ and control (without amendment). Each plot measured $6 \mathrm{~m} \mathrm{x}$ $6 \mathrm{~m}$ with $1 \mathrm{~m}$ inter- plot and replicate spacing. The site was cleared manually and organic manures incorporated into the soil during preparation of raised seedbeds of $25 \mathrm{~cm}$ depth using garden fork and spade while NPK (15:15:15) fertilizer was applied two weeks after planting according to treatment. A waterleaf landrace, locally called mmong mmong ikong Uyo was planted manually at a spacing of $5 \mathrm{~cm} \times 5 \mathrm{~cm}$ using stem cuttings of $10 \mathrm{~cm}$ length with leaves still attached. Manual weeding was carried out at 3,6 and 9, weeks after planting (WAP).

\subsection{Data Collection and Analysis}

Fifty plants were randomly selected and tagged per plot (excluding the border rows) for data collection. Growth and yield parameters measured included: height, number of leaves per plant, leaf area (determined graphically), number of branches per plant, stem girth (using an inelastic string around the stem) and total fresh foliage yield (i.e. from sequential harvesting done at 3,6, 9 and 12 WAP). Data collected were subjected to analysis of variance and means compared using least significant difference $(P=0.05)$.

\section{RESULTS}

\subsection{Plant Height and Number of Branches}

Table 1 shows that at $3,6,9$ and 12 WAP, there were significant differences $(P=0.05)$ in the height of waterleaf among the different fertilizer treatments in 2009. At 3, 6, 9 and 12 WAP, waterleaf in the $100 \mathrm{kgha}^{-1}$ of NPK +3.75 tha $^{-1}$ PM treatment was taller than those of other treatments by $12-15 \%, 9-54 \%, 13-55 \%$ and $12-15 \%$, respectively. The control treatment consistently produced the shortest waterleaf. Application of poultry manure alone at 5 tha $^{-1}$ enhanced plant height compared with the application of NPK alone at $400 \mathrm{kgha}^{-1}$. In 2010 , waterleaf height also differed significantly $(p=0.05)$ at all sampling months among the fertilizer treatments (Table 1). Percentage differences observed in waterleaf height in 2009 at the different sampling intervals were also maintained in 2010. Also, the use of poultry manure alone was better than the use of NPK (15:15:15) alone Table 2 shows that at 3, 6, 9 and 12 WAP, there were significant differences in the number of branches per plant $(P=0.05)$ among the different fertilizer treatments in 2009 but no clear pattern was maintained. However at 3 and 6 WAP, the $100 \mathrm{~kg} \mathrm{ha}^{-1}$ of NPK $+3.75 \mathrm{t} \mathrm{ha}^{-1}$ PM produced more branches per plant than other treatments by $28-56 \%$, and $19-46 \%$, respectively. At 9WAP, 5 tha $^{-1}$ poultry manure $(\mathrm{PM})$ produced $24-75 \%$ more branches than other treatments whereas at 
12WAP, the number of branches from the $300 \mathrm{kgha}^{-1} \mathrm{NPK}+1.25 \mathrm{tha}^{-1} \mathrm{PM}$ plot superseded other treatments by $52-78 \%$. The control treatment had the least number of branches per plant. In contrast, the number of branches per plant in 2010 in the $100 \mathrm{~kg} \mathrm{ha}^{-1}$ of NPK +3.75 $\mathrm{t} \mathrm{ha} \mathrm{A}^{-1} \mathrm{PM}$ treatment superseded others at $3,6,9$ and 12 WAP by corresponding differences of $17-58 \%, 11-43 \%, 4-40 \%$ and $17-55 \%$. Application of poultry manure alone produced more branches than the NPK $400 \mathrm{kgha}^{-1}$ treatment in both seasons.

Table 1. Waterleaf height $(\mathrm{cm})$ as influenced by organic/inorganic fertilizer combinations in 2009 and 2010 cropping seasons

\begin{tabular}{|c|c|c|c|c|}
\hline \multirow[t]{2}{*}{ Treatment } & \multirow{2}{*}{ Weeks } & after & \multicolumn{2}{|c|}{ planting } \\
\hline & & 6 & 9 & 12 \\
\hline & & 2009 & & \\
\hline $400 \mathrm{~kg}$ of NPK ha- ${ }^{1}$ & 8.3 & 9.6 & 9.3 & 8.6 \\
\hline 5tha ${ }^{-1}$ poultry manure (PM) & 8.8 & 10.7 & 10.9 & 9.8 \\
\hline $200 \mathrm{kgha}^{-1} \mathrm{NPK}+2.5 \mathrm{tha}^{-1} \mathrm{PM}$ & 13.3 & 15.3 & 14.4 & 13.7 \\
\hline $300 \mathrm{kgha}^{-1} \mathrm{NPK}+1.25 \mathrm{tha}^{-1} \mathrm{PM}$ & 11.8 & 13.7 & 13.2 & 12.4 \\
\hline 100kgha-1 NPK + 3.75tha ${ }^{-1}$ PM & 15.1 & 16.8 & 16.6 & 15.5 \\
\hline Control (no fertilizer Application) & 7.0 & 7.8 & 7.4 & 6.8 \\
\hline $\operatorname{LSD}(P=0.05)$ & 0.5 & $\begin{array}{l}0.4 \\
2010\end{array}$ & 0.5 & 0.5 \\
\hline $400 \mathrm{~kg}$ of NPK ha- ${ }^{1}$ & 4.9 & 7.2 & 6.1 & 5.1 \\
\hline 5tha ${ }^{-1}$ poultry manure (PM) & 6.3 & 7.2 & 74 & 6.5 \\
\hline $200 \mathrm{kgha}^{-1} \mathrm{NPK}+2.5 \mathrm{tha}^{-1} \mathrm{PM}$ & 8.1 & 8.7 & 8.6 & 7.7 \\
\hline $300 \mathrm{kgha}^{-1} \mathrm{NPK}+1.25 \mathrm{tha}^{-1} \mathrm{PM}$ & 7.6 & 8.4 & 8.8 & 6.2 \\
\hline $100 \mathrm{kgha}^{-1} \mathrm{NPK}+3.75 \mathrm{tha}^{-1} \mathrm{PM}$ & 9.8 & 9.8 & 9.2 & 9.3 \\
\hline Control (no fertilizer Application) & 4.1 & 5.6 & 5.5 & 4.2 \\
\hline $\operatorname{LSD}(P=0.05)$ & 1.3 & 1.5 & 1.4 & 1.7 \\
\hline
\end{tabular}

\subsection{Number of Leaves and Stem Girth}

In 2009 , the number of leaves per plant differed significantly $(P=0.05)$ among the different fertilizer treatments but showed no clear direction (Table 3). At 3 WAP, 200kgha ${ }^{-1} \mathrm{NPK}+$ 2.5 tha $^{-1}$ PM treatment had $9-47 \%$ more number of leaves per plant than others while at 6 and 9 WAP, the 5 tha $^{-1}$ poultry manure (PM) had $48-75 \%$ and $11-60 \%$ more number of leaves than others. The number of leaves in the $100 \mathrm{kgha}^{-1} \mathrm{NPK}+3.75 \mathrm{tha}^{-1} \mathrm{PM}$ plot superseded other treatments by $4-55 \%$.

All the fertilized plots had higher number of leaves per plant than the control treatment. Application of poultry manure alone produced more leaves than NPK $400 \mathrm{kgha}^{-1}$. The number of leaves per plant also differed significantly $(P=0.05)$ among the fertilizer treatments in 2010 (Table 3). At 3 WAP, 200kgha ${ }^{-1} \mathrm{NPK}+2.5 \mathrm{tha}^{-1} \mathrm{PM}$ treatment had $7-48 \%$ more leaves than others whereas at 6,9 and $12 \mathrm{WAP}$, the $100 \mathrm{kgha}^{-1}$ of NPK $+3.75 \mathrm{tha}^{-1} \mathrm{PM}$ produced $11-58 \%, 14-59 \%$ and $16-54 \%$ more number of leaves per plant than others. The control treatment consistently produced the least number of leaves per plant Application of poultry manure alone produced more leaves than application of NPK at $400 \mathrm{kgha}^{-1}$. 
Table 2. Number of branches per pant of waterleaf as influenced by organic/inorganic fertilizer combinations in 2009 and 2010 cropping seasons

\begin{tabular}{|c|c|c|c|c|}
\hline \multirow[t]{2}{*}{ Treatment } & \multirow{2}{*}{$\begin{array}{l}\text { Weeks } \\
3\end{array}$} & \multirow{2}{*}{$\begin{array}{l}\text { After } \\
6\end{array}$} & \multicolumn{2}{|c|}{ planting } \\
\hline & & & 9 & 12 \\
\hline & & 2009 & & \\
\hline $400 \mathrm{~kg}$ of NPK ha- ${ }^{1}$ & 5.7 & 7.2 & 6.0 & 5.1 \\
\hline 5tha ${ }^{-1}$ poultry manure (PM) & 6.5 & 7.2 & 21.3 & 6.4 \\
\hline $200 \mathrm{kgha}^{-1} \mathrm{NPK}+2.5 \mathrm{tha}^{-1}$ PM & 8.0 & 8.7 & 8.6 & 7.7 \\
\hline $300 \mathrm{kgha}^{-1} \mathrm{NPK}+1.25 \mathrm{tha}^{-1} \mathrm{PM}$ & 7.6 & 8.4 & 12.8 & 19.3 \\
\hline $100 \mathrm{kgha}^{-1} \mathrm{NPK}+3.75 \mathrm{tha}^{-1} \mathrm{PM}$ & 10.8 & 10.8 & 16.1 & 9.3 \\
\hline Control (no fertilizer Application) & 4.8 & 5.8 & 5.3 & 4.2 \\
\hline $\operatorname{LSD}(P=0.05)$ & 1.3 & $\begin{array}{l}1.6 \\
2010\end{array}$ & 1.7 & 1.2 \\
\hline $400 \mathrm{~kg}$ of NPK ha- ${ }^{1}$ & 5.0 & 7.2 & 6.1 & 5.1 \\
\hline 5tha ${ }^{-1}$ poultry manure (PM) & 6.3 & 7.2 & 7.4 & 6.5 \\
\hline $200 \mathrm{kgha}^{-1} \mathrm{NPK}+2.5 \mathrm{tha}^{-1} \mathrm{PM}$ & 8.1 & 8.7 & 8.6 & 7.7 \\
\hline $300 \mathrm{kgha}^{-1} \mathrm{NPK}+1.25 \mathrm{tha}^{-1} \mathrm{PM}$ & 7.6 & 8.4 & 8.8 & 6.2 \\
\hline $100 \mathrm{kgha}^{-1} \mathrm{NPK}+3.75$ tha $^{-1} \mathrm{PM}$ & 9.8 & 9.8 & 9.2 & 9.3 \\
\hline Control (no fertilizer Application) & 4.1 & 5.6 & 5.5 & 4.2 \\
\hline LSD $(P=0.05)$ & 1.3 & 1.46 & 1.4 & 1.7 \\
\hline
\end{tabular}

Table 3. Number of leaves per plant of waterleaf as influenced by organic/inorganic fertilizer combinations in 2009 and 2010 cropping seasons

\begin{tabular}{|c|c|c|c|c|}
\hline \multirow[t]{2}{*}{ Treatment } & \multirow{2}{*}{$\begin{array}{l}\text { Weeks } \\
3\end{array}$} & \multirow{2}{*}{$\begin{array}{l}\text { after } \\
6\end{array}$} & \multicolumn{2}{|c|}{ planting } \\
\hline & & & 9 & 12 \\
\hline & & 2009 & & \\
\hline $400 \mathrm{~kg}$ of NPK ha- ${ }^{1}$ & 10.2 & 12.9 & 13.4 & 13.3 \\
\hline 5 tha $^{-1}$ poultry manure (PM) & 14.1 & 39.1 & 26.2 & 24.2 \\
\hline $200 \mathrm{kgha}^{-1} \mathrm{NPK}+2.5 \mathrm{tha}^{-1} \mathrm{PM}$ & 15.7 & 18.6 & 18.7 & 15.9 \\
\hline $300 \mathrm{kgha}^{-1} \mathrm{NPK}+1.25 \mathrm{tha}^{-1} \mathrm{PM}$ & 14.3 & 18.6 & 20.6 & 20.9 \\
\hline $100 \mathrm{kgha}^{-1} \mathrm{NPK}+3.75 \mathrm{tha}^{-1} \mathrm{PM}$ & 13.6 & 20.3 & 23.4 & 24.3 \\
\hline $\begin{array}{l}\text { Control (no fertilizer } \\
\text { Application) }\end{array}$ & 8.3 & 9.7 & 10.4 & 10.9 \\
\hline $\operatorname{LSD}(P=0.05)$ & 1.4 & $\begin{array}{l}1.5 \\
2010\end{array}$ & 2.7 & 3.1 \\
\hline $400 \mathrm{~kg}$ of NPK ha- ${ }^{1}$ & 10.1 & 12.1 & 13.1 & 13.4 \\
\hline 5 tha $^{-1}$ poultry manure (PM) & 12.4 & 14.1 & 18.0 & 18.3 \\
\hline $200 \mathrm{kgha}^{-1} \mathrm{NPK}+2.5 \mathrm{tha}^{-1} \mathrm{PM}$ & 15.5 & 18.5 & 19.0 & 15.4 \\
\hline $300 \mathrm{kgha}^{-1} \mathrm{NPK}+1.25 \mathrm{tha}^{-1} \mathrm{PM}$ & 14.4 & 18.5 & 20.0 & 20.2 \\
\hline $100 \mathrm{kgha}^{-1} \mathrm{NPK}+3.75 \mathrm{tha}^{-1} \mathrm{PM}$ & 14.1 & 20.9 & 23.2 & 24.1 \\
\hline $\begin{array}{l}\text { Control (no fertilizer } \\
\text { Application) }\end{array}$ & 8.0 & 8.7 & 10.0 & 11.0 \\
\hline LSD $(P=0.05)$ & 1.3 & 1.5 & 2.6 & 3.0 \\
\hline
\end{tabular}

In 2009, stem girth at 3, 6, 9 and 12 WAP differed significantly (Table 4) among the different fertilizer treatments. Stem girth in the $100 \mathrm{kgha}^{-1}$ of NPK $+3.75 \mathrm{tha}^{-1} \mathrm{PM}$ plot was bigger than in other treatments at 3,6, 9 and 12 WAP by $13-55 \%, 7-28 \%, 7-29 \%$ and $6-73 \%$, respectively. The smallest stem girth was produced by the control treatment. Waterleaf stem girth differed significantly $(P=0.05)$ among fertilizer treatments in 2010 (Table 4) with the 
trend observed in 2009 maintained in 2010 . The application of $100 \mathrm{kgha}^{-1}$ of NPK +3.75 tha ${ }^{1} \mathrm{PM}$ resulted in the production waterleaf with bigger stem girth while the control consistently had the smallest stem girth. The application of poultry manure only had bigger stem girth than $400 \mathrm{~kg} \mathrm{ha}^{-1}$ of NPK $(15: 15: 15)$ treatment.

Table 4. Waterleaf stem girth $(\mathrm{cm})$ as influenced by organic/inorganic fertilizer combinations in 2009 and 2010 cropping seasons

\begin{tabular}{|c|c|c|c|c|}
\hline \multirow{2}{*}{ Treatment } & \multirow{2}{*}{$\begin{array}{l}\text { Weeks } \\
3\end{array}$} & \multirow{2}{*}{$\begin{array}{l}\text { after } \\
6\end{array}$} & \multicolumn{2}{|c|}{ planting } \\
\hline & & & 9 & 12 \\
\hline & & 2009 & & \\
\hline $400 \mathrm{~kg}$ of NPK ha- ${ }^{1}$ & 1.10 & 2.37 & 2.51 & 2.37 \\
\hline 5tha ${ }^{-1}$ poultry manure $(P M)$ & 1.27 & 2.30 & 2.43 & 2.53 \\
\hline $200 \mathrm{kgha}^{-1}$ NPK $+2.5 \mathrm{tha}^{-1}$ PM & 2.10 & 2.70 & 2.80 & 2.90 \\
\hline $300 \mathrm{kgha}^{-1} \mathrm{NPK}+1.25 \mathrm{tha}^{-1} \mathrm{PM}$ & 1.77 & 2.53 & 2.50 & 2.70 \\
\hline $100 \mathrm{kgha}^{-1} \mathrm{NPK}+3.75 \mathrm{tha}^{-1} \mathrm{PM}$ & 2.40 & 2.90 & 3.00 & 3.10 \\
\hline Control (no fertilizer Application) & 1.07 & 2.10 & 2.13 & 2.59 \\
\hline $\operatorname{LSD}(P=0.05)$ & 0.32 & $\begin{array}{l}0.15 \\
2010\end{array}$ & 0.19 & 0.84 \\
\hline $400 \mathrm{~kg}$ of NPK ha- ${ }^{1}$ & 1.12 & 2.38 & 2.48 & 2.32 \\
\hline 5tha ${ }^{-1}$ poultry manure $(P M)$ & 1.25 & 2.31 & 2.47 & 2.51 \\
\hline $200 \mathrm{kgha}^{-1} \mathrm{NPK}+2.5 \mathrm{tha}^{-1}$ PM & 2.12 & 2.75 & 2.85 & 2.94 \\
\hline $300 \mathrm{kgha}^{-1} \mathrm{NPK}+1.25$ tha $^{-1} \mathrm{PM}$ & 1.79 & 2.51 & 2.47 & 2.80 \\
\hline $100 \mathrm{kgha}^{-1} \mathrm{NPK}+3.75 \mathrm{tha}^{-1} \mathrm{PM}$ & 2.37 & 2.92 & 3.06 & 3.07 \\
\hline Control (no fertilizer Application) & 1.04 & 2.06 & 2.00 & 2.11 \\
\hline LSD $(P=0.05)$ & 0.29 & 0.17 & 0.16 & 0.86 \\
\hline
\end{tabular}

\subsection{Leaf Area and Total Foliage Yield}

Table 5 shows that at $3,6,9$ and 12 WAP, the leaf area of waterleaf differed significantly $(P=0.05)$ among the different fertilizer treatments in 2009. The leaf area in the $100 \mathrm{kgha}^{-1}$ of NPK +3.75 tha $^{-1}$ PM plot was larger than other treatments at $3,6,9$ and 12 WAP by $12-$ $45 \%, 16-53 \%, 5-39 \%$ and $11-43 \%$, respectively. The control treatment produced the smallest leaf area. Waterleaf leaf area was significantly $(P=0.05)$ influenced by the fertilizer treatments in 2010 (Table 5). The $100 \mathrm{~kg} \mathrm{ha}^{-1}$ of NPK $+3.75 \mathrm{t} \mathrm{ha}^{-1} \mathrm{PM}$ treatment produced the widest leaves and exhibited the same pattern observed in 2009 while the control treatment had the smallest leaf size. Generally, the 5 tha $^{-1} \mathrm{PM}$ treatment produced bigger leaves than sole application of $400 \mathrm{~kg} / \mathrm{ha}$ NPK (15:15:15) fertilizer.

Table 6 shows that, the total fresh foliage yield of waterleaf differed significantly $(P=0.05)$ among the different fertilizer treatments in 2009 and 2010 . The $100 \mathrm{~kg} \mathrm{ha}^{-1}$ of NPK $+3.75 \mathrm{t}$ $\mathrm{ha}^{-1} \mathrm{PM}$ treatment produced the highest total foliage yield $\left(56.03 \mathrm{tha}^{-1}\right.$ and 54.36 tha $^{-1}$ in 2009 and 2010, respectively) while the control had the least total foliage yield (12.12 $\mathrm{t} \mathrm{ha}^{-1}$ and 11.71 tha $^{-1}$, in 2009 and 2010 , respectively). The $100 \mathrm{kgha}^{-1}$ of NPK $+3.75 \mathrm{t} \mathrm{ha}^{-1} \mathrm{PM}$ treatment produced $38-78 \%$ and $35-78 \%$, more total foliage than other treatments in 2009 and 2010 , respectively. Foliage yield from the sole application of $5 \mathrm{tha}^{-1} \mathrm{PM}$ was higher than that of $400 \mathrm{~kg} \mathrm{ha}^{-1}$ NPK by $15 \%$ and $13 \%$ in 2009 and 2010 , respectively. There were slight differences in some of the parameters measured between 2009 and 2010 cropping seasons. 
Table 5. Waterleaf leaf area $\left(\mathrm{cm}^{2}\right)$ as influenced by organic/inorganic fertilizer combinations in 2009 and 2010 cropping seasons

\begin{tabular}{|c|c|c|c|c|c|}
\hline \multirow[t]{2}{*}{ Treatment } & \multirow{2}{*}{$\begin{array}{l}\text { Weeks } \\
3\end{array}$} & \multirow{2}{*}{$\begin{array}{l}\text { after } \\
6\end{array}$} & \multicolumn{3}{|l|}{ planting } \\
\hline & & & 9 & & 12 \\
\hline & & 2009 & & & \\
\hline $400 \mathrm{~kg}$ of NPK ha- ${ }^{1}$ & 7.97 & 10.70 & 8.84 & 8.31 & \\
\hline 5tha ${ }^{-1}$ poultry manure (PM) & 8.19 & 11.66 & 10.01 & 8.99 & \\
\hline $200 \mathrm{kgha}^{-1} \mathrm{NPK}+2.5 \mathrm{tha}^{-1} \mathrm{PM}$ & 10.63 & 14.48 & 12.99 & 11.28 & \\
\hline $300 \mathrm{kgha}^{-1} \mathrm{NPK}+1.25$ tha $^{-1} \mathrm{PM}$ & 9.80 & 13.31 & 11.09 & 10.07 & \\
\hline $100 \mathrm{kgha}^{-1} \mathrm{NPK}+3.75 \mathrm{tha}^{-1} \mathrm{PM}$ & 12.08 & 15.83 & 13.72 & 12.70 & \\
\hline Control (no fertilizer application) & 6.67 & 10.56 & 8.36 & 7.28 & \\
\hline LSD $(P=0.05)$ & 0.59 & 0.30 & 0.49 & 0.56 & \\
\hline $400 \mathrm{~kg}$ of NPK ha- ${ }^{1}$ & 8.01 & 10.72 & 8.80 & 8.36 & \\
\hline 5tha ${ }^{-1}$ poultry manure (PM) & 8.12 & 11.86 & 10.21 & 9.06 & \\
\hline $200 \mathrm{kgha}^{-1} \mathrm{NPK}+2.5 \mathrm{tha}^{-1} \mathrm{PM}$ & 11.12 & 15.03 & 13.01 & 11.57 & \\
\hline $300 \mathrm{kgha}^{-1} \mathrm{NPK}+1.25 \mathrm{tha}^{-1} \mathrm{PM}$ & 9.82 & 13.34 & 11.12 & 10.04 & \\
\hline $100 \mathrm{kgha}^{-1} \mathrm{NPK}+3.75$ tha $^{-1} \mathrm{PM}$ & 12.11 & 15.67 & 13.69 & 12.68 & \\
\hline Control (No fertilizer application) & 6.62 & 10.11 & 8.32 & 7.30 & \\
\hline $\operatorname{LSD}(P=0.05)$ & 0.62 & 0.41 & 1.26 & 1.13 & \\
\hline
\end{tabular}

Table 6. Total fresh foliage yield $\left(\right.$ tha $\left.^{-1}\right)$ of waterleaf as influenced by organic/inorganic fertilizer combinations in 2009 and 2010 cropping seasons

\begin{tabular}{lll}
\hline Treatment & $\mathbf{2 0 0 9}$ & $\mathbf{2 0 1 0}$ \\
\hline $400 \mathrm{~kg}^{-1}$ of NKK ha- & 19.73 & 20.06 \\
tha $^{-1}$ poultry manure $(\mathrm{PM})_{200 \mathrm{kgha}^{-1} \mathrm{NPK}+2.5 \mathrm{tha}^{-1} \mathrm{PM}}$ & 23.33 & 22.96 \\
$300 \mathrm{kgha}^{-1} \mathrm{NPK}+1.25 \mathrm{tha}^{-1} \mathrm{PM}$ & 34.93 & 35.13 \\
$100 \mathrm{kgha}^{-1} \mathrm{NPK}+3.75$ tha $^{-1} \mathrm{PM}$ & 28.40 & 27.99 \\
Control (no fertilizer application) & 56.03 & 54.36 \\
LSD (P=0.05) & 12.13 & 11.71 \\
\hline
\end{tabular}

\section{DISCUSSION}

Results of this study showed significant differences on all the vegetative characteristics and foliage yield. The study has also demonstrated that application of $5 \mathrm{t} \mathrm{ha}^{-1}$ of poultry manure alone performed better than the $400 \mathrm{~kg} \mathrm{ha}^{-1}$ treatment. However, combined application of 100 $\mathrm{kgha}^{-1} \mathrm{NPK}+3.75$ tha $^{-1}$ of PM resulted in increase in vegetative growth and foliage yield of waterleaf than other treatments. This may be due to synergistic effects of combining organic and inorganic fertilizers which optimally supplied needed plant nutrients. The mineral fertilizer supplied the needed nutrients to the waterleaf at the initial growth stage while the poultry manure provided the needed nutrients at later growth stages. Udoh et al. [3] and Ndaeyo et. al. [25] stated that the use of organic manure can enhance soil productivity and crop yield. Alves et.al [31] stressed the need to supplement organic manures with nitrogen fertilizers so as to increase nitrogen supply and in addition contribute to the increase in organic matter of the soil and other macro and micro nutrients required for crop growth. 
Most of the time, the best results came from plots amended with NPK at $100 \mathrm{~kg} \mathrm{ha}^{-1}+\mathrm{PM}$ at $3.75 \mathrm{t} \mathrm{ha}^{-1}$, which had the highest level of organic manure (PM) blended with mineral fertilizer. This agrees with that of Gill and Meelu [20] who found that crop yield increased with an increase in the level of nitrogen blended manure. Also combined application of organic manure and mineral fertilizers, particularly in the tropics, has additional advantages of buffering the soil against undesirable acidification and also increase the availability of micro nutrients $[28,26,34]$. Studies $[32,33,35]$ have also demonstrated that application of organic waste alone and in combination with mineral fertilizer enhanced root and shoot biomass, and general growth and yield and components of crops compared to sole application of NPK fertilizer (400 $\left.\mathrm{kgha}^{-1}\right)$. Similarly, Amalu and Oko [36] reported that yield performance was better in manured than in control plots and that responses varied very widely with sources of manures in terms of vegetative growth and yields. The variability in the performance of the fertilizer treatments could be due to variation in their nutrient composition since different ratios were combined [37]. Aliyu [37] and Dauda et.al. [16] also reported that application of poultry manure at 5 tha $^{-1}$ and farm yard manure at $5-10$ tha $^{-1}$ supplemented with $50 \mathrm{kgNha}^{-1}$ resulted in adequate crop growth and maximum fruit yield of pepper (Capsicum annum L) and water melon [Citrullus lanatus (Thum.) Matsum \& Nakai], respectively. Findings from the present study are in consonance with that of Abgede [38] who reported that combined application of sub-optimal rates of NPK fertilizer and poultry manure enhanced plant performance compared with application of NPK fertilizer or poultry manure alone. Also, Makinde et al. [29] in their findings stated that combined application of organic manures and mineral fertilizers, either as kola pod husk and pacesetter organic fertilizer at 3 tha $^{-1}$ alone or combined with NPK fertilizer at reduced levels, is suitable for vegetable production. Integrated nutrient management through combined use of organic wastes and chemical fertilizers has been reported to be an effective approach to combat nutrient depletion and promote sustainable crop productivity $[39,40,41,42]$. The slight differences observed in vegetative growth of waterleaf in both cropping seasons could be attributed to vagaries of weather.

\section{CONCLUSION}

With the high cost, scarcity, and environmental problems associated with the use of mineral fertilizer in Nigeria; and based on the foliage yield obtained in this study, it is obvious that the use of organic manure in combination with mineral fertilizer (particularly with $100 \mathrm{kgha}^{-1}$ $\mathrm{NPK}+3.75 \mathrm{tha}^{-1} \mathrm{PM}$ or $200 \mathrm{kgha}^{-1} \mathrm{NPK}+2.5 \mathrm{tha}^{-1} \mathrm{PM}$ treatment ) can sustain waterleaf production. It is also demonstrated that it would be more rewarding to apply 5tha ${ }^{-1} \mathrm{PM}$ alone compared to sole application of $400 \mathrm{kgha}^{-1}$ mineral fertilizer for waterleaf production in a Ultisol.

\section{COMPETING INTERESTS}

Authors have declared that no competing interests exist.

\section{REFERENCES}

1. Tindall HD. Vegetable in the Tropics. Macmillan Press Ltd. London.UK. 1983;342-346.

2. Idiong IC, Ekpe EE, Charles AI, Udoh EJ, Socio-economic determinants of waterleaf production in Calabar municipality and South Local Government Areas of Cross River State. Global Journal of Pure and Applied Science. 2002;8(2):239-243. 
3. Udoh DJ, Ndon BA, Asuquo PE, Ndaeyo NU, Crop Production Techniques for the Tropics. Concept Publication, Lagos. 2005;48-49:211-216.

4. Eyo EO, Ekpe O, Ogban PI. Waterleaf (Talinum triangulare Wild) in southeastern Nigeria: Existing practices and suggestions for increased productivity and profit. Global Journal of Pure and Applied Science. 2000;7(3):421-426.

5. Ibeawuchi II, Nwufo MI, Oti N,Opara CC, Eshett ET. Productivity of intercropping green (Amaranthus cruentus)/waterleaf (Talinum triangulare) with poultry manure rates in southeastern Nigeria. Journal of Science. 2007;2:222-227.

6. Ebenso IE, Okafor NM. Alternative diet for growing Archachatina marginata snails in southeastern Nigeria. Tropical Science. 2002;5(1):48-54.

7. Ipinmoroti RR, Adeoye GO, Daniel MA. The comparison of locally blended organic fertilizers on Amaranthus cruentus L. production at Ibadan southwestern Nigeria. Proceedings of Horticultural Society of Nigeria $21^{\text {st }}$ Conference, Ikorodu.2003; 58-65.

8. Fagbola O, Dare MO. Performance of pepper on simulated degraded and nondegraded soil as affected by mycorrhiza inoculation and organo-mineral fertilizer. Nigerian Journal of Horticultural Science. 2003;8:11-14.

9. Olowokere FA, Response of pepper and tomato intercrop to different rates and methods of application of poultry based organo-mineral fertilizer. Proceedings $29^{\text {th }}$ Annual Conference of Soil Science Society of Nigeria, UNAAB. 2004;186-191.

10. Adeoye GO, AdeOluwa OO, Oyekunle M, Shridhar MKC, Makinde EA, Olowoake AA. Comparative evaluation of organo-mineral fertilizer (OMF) and mineral fertilizer (NPK) on yield and quantity of maize. Nigerian Journal of Soil Science. 2008;18:132-137.

11. Ojeniyi SO, Adejobi KB. Effect of ash and goat dung manure on leaf nutrients composition, growth and yield of amaranthus. Nigeria Agricultural Journal. 2002;33:4657.

12. Ojeniyi SO, Owolabi O, Akinola OM, Odedina SA. Field study of effect of organomineral fertilizer on maize growth, yield, soil and plant nutrient composition in llesa, southwest Nigeria. Nigeria Journal of Soil Science. 2009;19:11-16.

13. Akanni DI, Ojeniyi SO, Residual effect of goat and poultry manures on soil properties and yield of amaranthus in southwest Nigeria. Research Journal of Agronomy. 2008; 2:44-47.

14. Makinde EA, Evaluation of organo-mineral fertilizer on growth and yield and quality of Amaranthus cruentus on two soil types in Lagos State, Nigeria. Ph.D. Thesis Department of Agronomy, University of Ibadan. Ibadan, Nigeria. 2007;154.

15. Steward MW,Dibb WD, Johnson ED, Johnson EA, Smith JT. The contribution for commercial fertilizer nutrients for food production. Agron J. 2005;327:(07):1-6.

16. Dauda SN, Ajayi FA, Ndor E. Growth and yield of water melon as affected by poultry manure application. J. Agric. Social Science. 2008;4:21-4.

17. Naeem M, Igbal J. Bakhsh MA. A comparative study of inorganic fertilizers and organic manures on yield and yield components of mung bean (Vigna radiata L.) Journal of Agriculture and Social Science. 2006;2:227-229.

18. Suresh KD, Sneh G, Krishn KK, Mool CM, Microbial biomass, carbon and microbial activities of soils receiving chemical fertilizers and organic amendments. Archives Agronomy Soil Science. 2004;50:641-647.

19. Arisha HA, Bradisi A. Effects of mineral fertilizers and organic fertilizers on growth, yield and quality of potato under sandy soil conditions. Zagazig Journal of Agricultural Resources. 1999;26:391-405.

20. Gill HS, Meelu OP Studies on the substitution of inorganic fertilizers with organic manure and their effect on soil fertility in rice- wheat rotation in India. International Journal on Fertilizer Use. 1982;3(4):303-307. 
21. Olsen RJ, Hensler RF, Attoe OJ. The effect of manure application, aeration and soil $\mathrm{pH}$ on soil nitrogen transformations on certain soil texture values. Soil Sc. Amer. Proc, 1986;34:222-225.

22. Ndaeyo NU, Ukpong ES, John NM. Performances of okra as affected by organic and inorganic fertilizers on an Ultisol. In Orheruata AM, Nwokoro SO, Ajayi MT, Adekunle GN, editors. Proceedings of the 39th Annual Conference of the Agricultural Society of Nigeria held at the University of Benin. Benin City.Nigeria. Ambik Press Ltd. Benin City. 2005;206-209.

23. Kang BT, Balasubramanian V. Long term fertilizer trials on Alfisol in West Africa. In:Transactions of XIV International Soil Science Society Congress. Kyoto,Japan. 1990;350.

24. Bayu W, Rethman NFG, Hannes PS, Alemu G. Effect of farm yard manure and inorganic fertilizers on sorghum growth, yield and nitrogen use in a semi arid area of Ethiopia. J. of Plant Nutrition. 2006;29(10):391-407.

25. Ndaeyo NU, Harry GI Ekpo IW. Growth of Celosia argentea as influenced by complementary use of organic and inorganic fertilizers. In: Olufajo OO, Omokore DF Akpa GN, Sanni SA, editors. Reviving Agriculture for Sustainable national Growth and Stable Democracy. Proceedings of the 41st Annual Conference of the Agricultural Society of Nigeria held at Institute for Agricultural Research, Samaru. Ahmadu Bello University, Zaria. 22-26 October. 2007;62-65.

26. Ikeh AO, Ndaeyo NU, Uduak IG, Iwo GA, Ugbe LA, Udoh El, Effiong GS. Growth and yield responses of pepper (Capsicum frutescens I.) to varied poultry manure rates in Uyo, Southeastern Nigeria. ARPN Journal of Agricultural and Biological Science. 2012;7(9):735-742.

27. Lombin LG, Adepetu JA, Ayotade KA. Organic fertilizer in the Nigeria agriculture: Present and future. F.P.D.D. Abuja, Nigeria. 1991;146-162.

28. Agboola AA, Ndaeyo NU, Kalu OI. Soil fertility management alternatives to inorganic fertilizer use. In: Babalola O, Babaji GA, Mustapha S editors. Soil management for sustainable agriculture and environmental harmony. Proceedings of the $24^{\text {th }} 244$ Annual Conference of the Soil Science Society of Nigeria held at the Abubakar Tafawa Balewa University, Bauchi 7-14 December. 1998;1-9.

29. Makinde EA, Ayeni LS, Ojeniyi SO, Odedina JN. Effect of organic, organo-mineral and NPK fertilizer on nutritional quality of amaranthus in Lagos, Nigeria. Researcher 2010;2(2):91-96.

30. Peters SW, Usoro EJ, Udo EJ, Obot UW, Okpon SN, editors. Akwa Ibom State: Physical background, soils and land use and ecological problems. A technical report of the task force on soils and land use survey, Akwa Ibom State. 1989;603.

31. Alves BJ, Urqulaga RS, Gadisch G, Souto CM, Bodde RM. In: site estimation of soil nitrogen mineralization. Soil organic matter dynamics and sustainability of tropical agriculture. Proceedings of the Laboratory of Soil and Soil Biology. Leuven, Belgium. 1993;173-174.

32. Odu CTI, Mba CC. Mineral consideration for maximizing nutrient availability through organic fertilisation. In: Proceedings organic fertilizer seminar. Durbar Hotel, Kaduna. 1991;69-80.

33. Ano AO, Agwu JA. Effect of animal manures on selected soil chemical properties. Nigerian J Soil Sci. 2005;15:14-19.

34. Ogundare K, Agele S, Aiyelari P. Organic amendment of an Ultisol: effects on soil properties, growth, and yield of maize in Southern Guinea savanna zone of Nigeria. International Journal of Recycling of Organic Waste in Agriculture. 2012;1(11):1-11. 
35. Obi ME, Ebo PO. The effects of organic and inorganic amendments on soil physical properties and maize production in a severely degraded sandy soil in southern Nigeria. Bioresource Tech. 1995;51:117-123.

36. Amalu UC, Oko BDF. Response of waterleaf vegetable (Talinum triangulare Jacq) to nitrogen and organic fertilizer. Global Journal of Pure and Applied Sciences. 2001;1:712.

37. Aliyu L. The effect of organic and mineral fertilizers on growth, yield and composition of pepper (Capsicum annum L.) Biological Agriculture and Horticulture. 2000;18(1):29- 36.

38. Agbede TM. Tillage and fertilizer effects on some soil properties, leaf nutrient concentration, growth and sweet potato yield on an Alfisols in southwestern Nigeria. Soil and Tillage Research. 2010;110(1):25-32.

39. Adeniyan ON, Ojeniyi SO. Effect of poultry manure NPK 15-15-15 and combination of their reduced levels on maize growth and soil chemical properties. Niger J Soil Sci. 2005;15:34-41.

40. Paul GC, Mannan MA. Integrated nutrient management in sugarcane to enhance sugar productivity. In: Proceedings, international symposium on technologies to improve sugar productivity in developing countries. Gullin. 2006;108-121.

41. Agele SO, Adeyemo AJ, Famuwagun IB. Effects of agricultural wastes and mineral fertilizer on soil and plant nutrient status, growth and yield tomato. Arch. Agronomy Soil Sci. 2011;57(1):91-104.

42. Asadu CLA, Nwajiaku IM. The effects of four ratios of organic to inorganic manures on soil physicochemical properties and maize yield. Agro-Science. 2012;10(1):1-6.

(C) 2013 Ndaeyo et al.; This is an Open Access article distributed under the terms of the Creative Commons Attribution License (http://creativecommons.org/licenses/by/3.0), which permits unrestricted use, distribution, and reproduction in any medium, provided the original work is properly cited.

Peer-review history:

The peer review history for this paper can be accessed here: http://www.sciencedomain.org/review-history. php?iid=203\&id=2\&aid=1068 